\title{
Botanical Lotion CG428
}

National Cancer Institute

\section{Source}

National Cancer Institute. Botanical Lotion CG428. NCI Thesaurus. Code C125063.

A proprietary lotion containing a blend of the four botanicals Allium cepa L. (Onion), Citrus limon L. (Citrus), Theobroma cacao L. (Cocoa), Paullinia cupana (Guarana), with potential activity ag ainst chemotherapy-induced alopecia (CIA). Upon administration to the scalp, botanical lotion CG428 may normalize the apoptotic process of hair follicular cells and reduce inflammation in the scalp. This may reverse chemotherapy-induced alopecia (CIA), restore the natural hair cycle, improve hair regrowth, and improve the psychosocial wellbeing of the affected patient. 